\title{
The Geographies of Knowledge Transfers over Distance: Toward a Typology
}

\author{
Harald Bathelt \& Sebastian Henn
}

\begin{abstract}
Version Post-print/accepted manuscript
Citation Bathelt, H., \& Henn, S. (2014). The geographies of knowledge transfers (published version) over distance: Toward a typology. Environment and Planning A, 46(6), 1403-1424.

Copyright / License

Publisher's Statement The version of record [Bathelt, H., \& Henn, S. (2014). The geographies of knowledge transfers over distance: Toward a typology. Environment and Planning A, 46(6), 1403-1424.] is available online at: http://epn.sagepub.com/content/46/6/1403 [doi: $10.1068 / \mathrm{a} 46115]$
\end{abstract}

Always cite the published version, so the author(s) will receive recognition through services that track citation counts, e.g. Scopus. If you need to cite the page number of the TSpace version (original manuscript or accepted manuscript) because you cannot access the published version, then cite the TSpace version in addition to the published version using the permanent URI (handle) found on the record page. 


\section{The Geographies of Knowledge Transfers over Distance: Toward a Typology}

by

\section{Harald Bathelt}

University of Toronto, Department of Political Science and Department of Geography \& Program in Planning, Sidney Smith Hall, 100 St. George Street, Toronto ON M5S 3G3, Canada; E-mail: harald.bathelt@utoronto.ca, URL: http://www.harald-bathelt.com

and

\section{Sebastian Henn}

Leibniz-Institute for Regional Geography, Schongauerstr. 9, 04328 Leipzig, Germany;

E-mail: s_henn@ifl-leipzig.de,

URL: http://www.sebastian-henn.com

To be re-submitted to

Environment and Planning A 


\title{
The Geographies of Knowledge Transfers over Distance:
}

\section{Toward a Typology}

\begin{abstract}
In the globalizing knowledge economy, firms have become less reliant on local production and market networks and increasingly expand their reach to an international or global scale. The argument of this paper suggests that this has given rise to distinct geographies of knowledge transfers over distance, which rely on periodic or regular temporary face-to-face contacts. While some of these settings of temporary knowledge transfers have existed for a long time, they are now being intensively applied throughout the economy. In this paper, we develop a typology of these geographies based on three dimensions that characterize the conditions for knowledge exchange: (i) framing, (ii) cognitive focus and goals, and (iii) trust and risks involved. Based on these variables, we identify three configurations and eight subcategories of knowledge transfers that build upon temporary face-to-face interaction, classified as (1) international community gatherings, (2) international business travel, and (3) transnational network relations. Systematic comparison reveals that with growing uncertainty in economic interaction and with increasing commitment between the agents, trust-based linkages tend to become more important and the number of interacting agents declines, while the frequency of temporary face-to-face meetings increases.
\end{abstract}

Keywords: Geographies of knowledge transfers over distance; temporary vs. permanent proximity; international community gatherings; international business travel; transnational network relations

JEL Codes: D80, F20, L00, R10

\section{Introduction}

In the context of the globalizing knowledge economy, economic growth and competiveness are increasingly dependent on trans-local, inter-regional and international knowledge flows between firms and their distant partners. The underlying debate about the spatial architectures of learning and knowledge creation has given rise to what could be called a bifurcated literature: One stream of the literature focuses on localized knowledge networks in territorial production systems that develop into regional clusters or innovation systems based on local culture and trust (Porter 1990; Cooke and Morgan 1998; Malmberg and Maskell 2002). Another stream emphasizes international/transnational networks in organizing production and marketing within value chains and facilitating knowledge flows 
across distant settings (Gereffi 1994; Dicken et al. 2001; Humphrey and Schmitz 2002). While the former literature discusses the advantages of local/regional relationships and networks based on permanent spatial proximity, the latter work focuses on the organization and coordination of wider international and transnational production networks highlighting issues of governance and power relations.

In recent years, contributions from both streams of literature have emphasized the need of combining local/regional with national/international perspectives on knowledge flows. Along with this, it has been recognized that it is important to link distant economic centers of activity through various forms of ongoing, periodic or temporary face-to-face interaction (Humphrey and Schmitz 2002; Malmberg and Maskell 2006; Bathelt and Glückler 2011). Indeed, the argument of this paper is that combinations of electronic and digital translocal communication with temporary face-to-face meetings provide efficient ways of linking different locations of production, research and marketing with one another. Such settings form distinct 'geographies' that connect local, regional, national and international production contexts and generate linkages across them. They provide the architecture for flows of goods, people and knowledge, and generate the basic conditions for globalization processes in current capitalism (Giddens 1984). In fact, one could argue, that these practices are common to large and small firms, as well as to manufacturing and service activities in both urban and peripheral contexts, thus greatly supporting the radical integration of global economic structures and activities in contemporary capitalism.

Although the importance of such configurations has also been recognized as being key to economic interaction in the globalizing knowledge economy (Thrift 2000; Amin and Cohendet 2004; Bathelt and Glückler 2011), limited comparative analysis has been conducted to explore their diverse nature and pervasive role. While the literature provides a rather fragmented picture of these geographies of global knowledge transfers, systematic 
comparison allows us to identify the specific conditions of and potential complementarities between different learning settings. In this context, the agenda of this paper is to discuss the broader importance of knowledge transfers over distance by structuring the elements and characteristics of those geographies that link distant settings through regular - occasional, periodic or frequent - temporary face-to-face meetings.

To formulate a framework that integrates the various settings of distant knowledge transfers, we first identify the specific agendas and circumstances of temporary interactions. Second, by building on previous empirical studies, we describe the nature and the conditions of knowledge exchange and learning in these settings. Third, we reveal the corresponding relationships between different forms of permanent versus temporary proximities, spatial versus non-spatial affinities and trust versus risk trade-offs. Based on these fundamental dimensions, this paper develops a typology as an initial framework for further development, thereby contributing to the growing literature on knowledge transfers over distance.

To conduct an analysis of different constellations of knowledge transfers that is both conceptual and comparative in nature, we focus on typical constellations, rather than discussing all possible outcomes or deviations. As such, our choices are selective ${ }^{1}$ (Maskell et al. 2006; Rallet and Torre 2009; Bathelt and Turi 2011), and our characterization necessarily simplifies some of the processes in order to identify common characteristics and practices of trans-local business relations in the globalizing knowledge economy (Amin and Cohendet 2004).

${ }^{1}$ For instance, we do not include virtual interaction contexts, such as global virtual teams or Internetbased social networks (e.g., Maznevski and Chudoba 2000; Grabher et al. 2008), which sometimes also require face-to-face meetings. In fact, our assumption is that electronic and digital communication complement and enable the knowledge generation contexts discussed here. 
Using this as a starting point, section 2 presents a conceptual discussion of the different geographies of making trans-local or global connections by combining temporary with permanent settings of interaction. From this, the principal dimensions for the development of a typology of knowledge transfer settings over distance are discussed in section 3. The sections that follow systematically characterize the framing, cognitive focus/learning and trust/risk contexts of different settings of knowledge transfers, distinguishing between international community gatherings (section 4), international business travel (section 5) and transnational network relations (section 6). Section 7 concludes and draws implications for future research.

\section{Making Global Connections - Combining Temporary and Permanent Settings}

In the past decade, cross-national knowledge flows have increasingly attracted the interest of economic geographers and resulted in different strands of literature: First, research on local/regional clusters and innovation systems has emphasized that industrial agglomerations, in order to be successful in the long-run, have to move beyond the range of regional networks/resources and connect systematically with resources, transaction partners and markets outside their regional boundaries on a worldwide basis (Malmberg and Maskell 2006; Bathelt and Glückler 2011). It is the existence of such trans-local pipelines that generates access to new knowledge pockets and provides the basis for discontinuous innovation (Owen-Smith and Powell 2004). From a knowledge-based perspective of clusters, it has been emphasized that the nature of knowledge flows within localized industry settings - i.e., so-called local buzz - is much different from the more selective, directed and sometimes costly trans-local knowledge linkages - i.e., so-called global pipelines (Bathelt and Turi 2011; Fitjar and Rodriguez-Pose 2011). 
Second, in recognizing the importance of international and transnational economic linkages, the literature on global value chains and production networks has emphasized the challenges and complexities in organizing and maintaining knowledge linkages that cut across national borders (Humphrey and Schmitz 2002; Gereffi et al. 2005; Coe et al. 2010). In such contexts, firms are connected that operate under fundamentally different institutional settings and are influenced by different cultural traditions. The corresponding literature analyzes how different transaction settings and power relations play out in various industry configurations and how this leads to different types of chains and learning dynamics that have distinct consequences for the development and upgrading of industries in different parts of the world. Typically, the focus of such studies has been directed towards the governance of highly complex global production and knowledge networks involving large numbers of firms (Humphrey and Schmitz 2002; Coe et al. 2010).

Third, research on proximity dimensions acknowledges that the organization of such cross-national production configurations is not a routine process. Rather, in focusing on the control mechanisms of economic processes, the shift from local towards international and global production settings is accompanied by increasing diversity in institutional and cultural contexts, thus adding uncertainties and risks to these forms of organization (Rallet and Torre 1999; Boschma 2005). The corresponding literature suggests that firms can use specific strategies to overcome hurdles and reduce the degree of uncertainty in production - for instance, by generating new or exploiting existing organizational or relational affinities (proximities) associated with foreign affiliates (e.g., Malecki 2010).

Although research on clusters, transnational networks and proximity relations applies different perspectives to analyze trans-local knowledge transfer processes, individually these approaches are limited in developing a comprehensive framework. What appears to be lacking is, first, recognition of the importance, widespread character and multiplicity of 
different constellations of knowledge transfers over distance. Second, a systematic discussion does not exist of how different forms of knowledge transfers over distance can be initiated or enabled, and how these forms provide preconditions for the establishment of 'knowledge pipelines' in transnational or global production networks.

Similar to economic geography, discussions in social psychology have traditionally emphasized the importance of face-to-face-based interaction (Walther et al. 2005; Short et al. 1976). At the same time, it has been shown that social relations in economic interaction can even be established without permanent co-location, based on computer-mediated, text-based communication (Olson and Olson 2003; Walther et al. 2005) or modern Internet-based social networks alone (e.g., Leamer and Storper 2001; Jeppesen and Molin 2003). If such computermediated communication can already stimulate the development of reciprocal ongoing interfirm relations, we can imagine how much greater the potential for close relationships is, if patterns of Internet-based and face-to-face interaction are combined with one another. Rather than viewing such different contexts of communication as competing with one another, their potential appears much greater when applied simultaneously (De Meyer 1991; McDonough et al. 1999). It should be added that distant learning and knowledge transfers are even more effective if agents already share relational proximity based on former joint work experience or close social relations (Amin and Cohendet 2004; Bathelt and Glückler 2011).

In reality, we find widespread practices of economic interaction that make use of multiple constellations of interaction and communication thus enabling knowledge transfers between actors from permanently separated entities at an international scale in efficient ways and at relatively low risk. It is this context that we investigate the potential of temporary faceto-face settings to accommodate interactions between economic agents and generate knowledge transfers over distance. In the next section, we develop a typology of such settings and systematically analyze the different forms of interactions as expressions of global 
geographies of knowledge transfers over distance. While the literature has treated the various configurations as separate phenomena, we suggest that they have collectively gained in importance as globalization processes have intensified since the 1990s and as international production settings have become widespread learning platforms in the modern knowledge economy.

\section{Dimensions of Knowledge Transfers over Distance}

Any typology of combinations of distant and co-present economic interaction representing the diverse global geographies of knowledge transfers needs to focus on the way of how interaction is organized, on the combination of individual and collective goals and incentives involved, as well as on the specific forms of how knowledge is exchanged. As argued below, such interaction is fundamentally structured by and dependent upon (i) the context and framing of knowledge exchange, (ii) the cognitive focus and goals of face-to-face meetings, and (iii) the risks of interactions and associated trust requirements. These dimensions are used to further differentiate specific subcategories of knowledge transfers over distance.

(i) Framing. Depending on the basic environment and set-up of the respective meetings, such as periodicity, duration, place and size, the participants have different expectations, notice different features and act differently. Temporary meetings can also be viewed as sociological frames (e.g., Skov 2006) that help actors to define situations in which they can present themselves in an adequate manner and make sense of their perceptions, thereby 'setting the stage' for knowledge transfers during these meetings (Bateson 1972; Goffman 1974).

(ii) Cognitive focus and learning. The creation of new knowledge requires that the actors involved have sufficiently different knowledge bases (Nooteboom 2000). At the same time, however, they need to have similar cognitive foci in order to efficiently communicate 
and understand each other (Cohen and Levinthal 1990). While this is clearly necessary for interaction at the local level, it seems even more important in an international context, in which agents act upon different norms and speak different languages - all of which may hamper knowledge flows (McDonough et al. 1999; Gertler 2003; Bathelt and Glückler 2011). In our typology, we incorporate related aspects by investigating the common basis of interaction, which strongly impacts cognitive affinity between the actors. As the transfer of knowledge may be facilitated through different types of affinities or proximities (e.g., Rallet and Torre 1999; 2009; Boschma 2005), we identify those proximity dimensions that are characteristic of the different settings, which, in turn, impact the type of knowledge exchanged.

(iii) Trust and risks. The exchange of certain types of knowledge may involve risks related to opportunistic behavior of partners. Such risks become more likely when firms originate from geographically distant locations and meet only temporarily. In such settings, it may be difficult to monitor other firms or to prosecute parties that fail to comply. Different kinds of trust may be mobilized to deal with behavioral uncertainties in interaction thereby reducing existing risks (Gulati 1995; Gertler 2003; Murphy 2006). Furthermore, potential sanctions that can be enforced through third parties (e.g., courts) or collective action (e.g., discharge from families) may help to avoid the misuse of trust and stabilize interactions and knowledge flows between the actors (Coleman 1990; Portes and Sensenbrenner 1993; Herreros and Criado 2008). Our typology considers the potential risks associated with different settings of knowledge transfers over distance, the kinds of trust that exist between the agents involved (or that is required) and the potential sanctions which can be imposed upon other agents to secure cooperation.

Based on these criteria, we identify three types of configurations of transfers of market- and production-related knowledge over distance that systematically involve 
temporary face-to-face meetings. According to the nature of meetings and the combination of actors engaged, we refer to these types as: (1) international community gatherings, ${ }^{2}$ (2) international business travel and (3) transnational network relations. ${ }^{3}$ These different configurations and their subcategories are discussed below. ${ }^{4}$

\section{International Community Gatherings}

International gatherings of communities involving a broader - sometimes global - set of specialists and firm representatives from an industry or technology field, encompass trade fairs - especially international flagship fairs - as well as corporate conferences and conventions (Table 1). These gatherings have in common that they are planned, last for only one or few days, and occur with a periodicity of one meeting per year or every few years. They typically involve additional spectacle, cultural events and take place in dedicated trade fair, exhibition or convention centers. Places of such events also include luxury hotel complexes with integrated large-scale conference facilities (McNeill 2009), often characterized by modern infrastructure and flamboyant architecture. The location of these centers in the urban landscape varies. In numerous cities, they are located close to the downtown area or even in the center of a metropolitan area, while other cities have modern meeting places in peripheral locations, close to a larger airport. Often, the destination of an event becomes an “" 'add-on' to the essential purpose of the meeting itself” (Hiller 1995: 376).

\footnotetext{
${ }^{2}$ Even though these meetings are temporary in nature, the agents may be part of permanent
} communities of practice or epistemic communities.

${ }^{3}$ In our discussion, projects are not listed as a distinct category since each of the settings can "provide the social and organizational fabric for temporary and recurrent collaboration in projects" (Grabher 2003: 75), thereby facilitating the formation of project ecologies.

${ }^{4}$ We have to consider that all of these temporary face-to-face meetings may give rise to different forms of routinized or follow-up contacts. Such follow-ups will, however, not be dealt with in this paper. 
Occasional community gatherings bring together hundreds or even thousands of firm representatives. Agents, who attend, have broad, often not clearly defined agendas and are interested in short-term intensive exchanges. Although long-term relationships between firms may develop, this is not imperative and, usually, happens later.

Insert Table 1 about here

\subsection{Trade Fairs}

(i) Framing. International trade fairs bring together large communities of executives, technical specialists, sales managers, researchers, as well as media representatives and multipliers, related to an entire industry or value chain. They sometimes form a "microcosm of the industries they represent" (Rosson and Seringhaus 1995: 87) engaging in broad, intensive, short-term interaction with each other. The participants have clear roles as exhibitors, buyers, potential customers/suppliers, economic partners or multipliers - or perform several roles at the same time (such as being both exhibitors and visitors). Most trade fairs also involve convention and conference elements through which they share similarities with the latter types of events. Participants at trade fairs get in contact with one another in different ways, for instance by visiting exhibition booths or during dinner conversations. Sometimes, face-to-face meetings are arranged prior to the gathering or follow a prepared pattern, but, often, there are also spontaneous, random interactions through combinations of on-site and off-site meetings (Bathelt and Schuldt 2010).

The goals of the participating firm representatives are manifold, diverse and diffuse. Many exhibitors just want to present their production program and innovations to a broad audience or to inform themselves about new developments in a global industry setting. However, other firms have more specific goals. They may look for new technologies or 
artifacts to be applied to their production contexts or be interested in new ideas for future innovation; or their goal may be to find potential future customers and suppliers or deepen contact with existing ones. Additionally, some firms also interact in more conventional ways by buying or selling products or negotiating contracts during a fair. ${ }^{5}$

Often these gatherings do not end with a specific set of actions or a final conclusion, but are starting points for further inquiries and become integral parts of decision-making processes that take place later on. As a consequence of the diffuse practices of learning by interaction and learning by observation (Rinallo and Golfetto 2006), trade fairs generate what has been referred to as 'global buzz' - a specific knowledge ecology that helps reduce uncertainties regarding market and technology development (Maskell et al. 2006; Bathelt and Schuldt 2010). Participants, when they return home, share up-to-date knowledge within their firms about the state of the industry, thus supporting decisions regarding future production and helping to make adjustments to existing production patterns.

(ii) Cognitive focus and learning. The common basis for interaction during a trade fair is the industry, technology or value-chain focus of the participants. The participants have a partly overlapping, partly deviating knowledge bases, related to their positions and functions (Bathelt and Schuldt 2010), and, thus, share a knowledge body that is cognitively related (e.g., Nooteboom 2000). Interactions during trade fairs are generally focused on the artifacts presented and their characteristics (Borghini et al. 2006). The type of knowledge that is exchanged and circulated varies, however. It is often primarily codified in character, but also involves important systemic/architectural or design elements that allow experienced participants to make implications about tacit components of the exhibits and their foundational principles.

${ }^{5}$ Empirical studies that have investigated such practices include Borghini et al. (2006), Power and Janssen (2008), Ramírez-Pasillas (2008) and Schuldt and Bathelt (2011). 
(iii) Trust and risks. Although repeated meetings during the cycle of trade fairs in an industry help to create personal relationships over time (Power and Janssen 2008), trust usually does not play a key role in interactions. This is because initial commitments are low and risks limited. Some visitors may steal ideas or copy designs, but organizers establish rules to minimize such adverse behavior, for instance, by systematically separating out exhibits with evidence of intellectual property right infringements or by banning visitors from taking photos (Bathelt and Schuldt 2010).

\subsection{Conferences and Conventions}

(i) Framing. Conferences (and similarly conventions) bring together firm representatives from a specific community defined around a joint topic of interest, such as investment specialists in an investment conference or members of a professional association in an annual meeting. The participants establish a closely defined community of specialists with similar educational backgrounds, functions and experiences in their respective firms. They form an epistemic community (Knorr Cetina 1999) that shares certain codes of conduct in doing business. Such a setting even stimulates discussions between representatives of firms that are direct competitors in the same market segments. A key component of conferences, more so than of trade fairs, is their organization around well-known researchers and broadlyrespected experts in the field. By giving keynote speeches and presentations, these key individuals contribute fundamentally to the collective sense-making that takes place at these events. Through their statements and comments, they become reference points for evaluations of other participants. When conferences are rigidly planned and arranged by the organizers around a new core technology, they may develop into field-configuring events (Lampel and Meyer 2008), but such events are not very frequent. Participants join conferences based on self-selection or designation, depending on the specific topics discussed and the likely presence of other participants. The more specific a business conference, the more likely firm 
representatives know other attendees or similar specialists from previous such events. Often conferences also have a trade fair component where producers - sometimes the participating firms themselves - exhibit artifacts closely related to the conference topic and the specific community that meets. ${ }^{6}$

Conventions in the sense of total-membership meetings (e.g., annual meetings of professional associations) (Lawson 1980) also involve keynote speakers, such as politicians or industry leaders. Compared to conferences, however, these events do not primarily aim at presenting new developments, but rather at creating a sense of togetherness by stressing the role and relevance of the organizing body. In addition, conventions include presentations that inform about past developments, future plans and the distribution of resources, as well as about awards and charities. As they bring together members of an organization or association in a particular technology or industry field, there is a high probability that the participants get to know each other over time. Frequently, conventions include elements of trade fairs and/or conferences (Zelinsky 1994).

The principal agenda of firms participating in conferences is to listen to state-of-theart presentations on specific business functions, for instance related to new developments in technology platforms, marketing or disaster management, and to discuss the relevance of these topics with other participants. Several goals can be associated with this (e.g., Garud 2008): Firms may be interested in a rigorous discussion of competing technical solutions and in participating in collective interpretation and sense-making processes. Additionally, firms may try to achieve a temporary competitive advantage or a head start from the conference discussions, compared to other firms that do not participate. Aside from official discussions and debates, off-site lunch or evening discussions can be important in evaluating the potential

${ }^{6}$ Although empirical evidence regarding knowledge creation is limited, an illustrative case study can be found in Möllering (2010). 
of new solutions, making new contacts and searching for solutions to shared problems. In contrast, conventions aim at legitimizing past developments and at finding consensus about intended future paths (i.e., in the form of generating roadmaps) (Ladkin and Spiller 2000). This may include elections of board members and discussions about future strategies. Like conferences, conventions also generate opportunities for informal discussions (e.g., receptions) that allow for the establishment of contacts and the exploration of future cooperations (McIntyre et al. 2007).

(ii) Cognitive focus and learning. In the case of conferences and conventions, the attendees' cognitive focus that enables important knowledge exchange is closely related to the knowledge base of the respective epistemic community (Knorr Cetina 1999) and the existence of similar goals of participation. Exchanges are based on cognitive and social proximity as many participants have similar positions in their firms and face similar sets of problems. While the knowledge circulated via presentations is largely codified in nature, the participants share similar tacit experiences associated with this knowledge when translating it into corporate contexts (Möllering 2010).

(iii) Trust and risks. The risk of interaction is low as long as participants avoid talking about sensitive contexts. Interaction is not based on and does not require personal trust, but, instead, builds upon professional and institutional trust related to the code of conduct of the profession (e.g., Bachmann 2001; Murphy 2006). If individuals misbehave or gossip too much, or if they are biased and prejudiced, other participants can easily avoid them or immediately end a discussion. In general, however, attendees come with a mindset of sharing ideas and knowledge. An important learning mechanism of such events is thus related to transferring experiences of others into their own business context and focuses on horizontal learning from competitors ( $\mathrm{Li} 2012)$. 


\section{International Business Travel}

In comparison with gatherings of global communities, international business travel involves fewer individuals - usually executives, decision-makers or highly specialized technical staff - who meet in order to coordinate production between different spatially separated corporate sites, engage in ongoing producer-user collaboration or prepare strategic business decisions, such as takeovers, mergers or strategic alliances (Table 2). These meetings take place several times a year, ranging from weekly coordination meetings to annual meetings with corporate customers discussing ongoing collaborations. Meeting places are often the corporate plants or specific sites of production that are of interest. An exception are negotiation meetings in preparation of strategic decisions between two firms, which tend to take place on neutral ground, possibly in luxurious conference or airport hotels (e.g., McNeill 2009).

The duration of these meetings is relatively short, usually lasting several hours to a few days. When agents travel to such meetings, they have a clearly defined, well-prepared agenda that is directed to maintaining or adjusting existing trans-local relationships or creating new ones. As opposed to the diffuse community gatherings, these forms of business travel involve medium- or long-term commitments. Two types of practices can be distinguished in this respect: On the one hand, business travel may be open-ended and become standard practice in ongoing producer-user relations or intra-firm communication.

On the other hand, such travel may be project-related and continue only until an intra-firm or inter-firm project has been terminated (Grabher 2004; Ibert 2004), or until a collaboration/merger agreement has been signed. In most cases, firms connect with their international business environment by the means of regular air travel (Wickham and Vecchi 2008; Beaverstock et al. 2009; Faulconbridge et al. 2009). 
Insert Table 2 about here

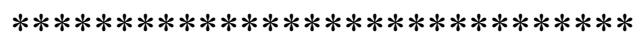

\subsection{Intra-firm Business Coordination}

(i) Framing. These meetings typically involve middle/upper management and technical specialists travelling back and forth between different corporate affiliates. Such meetings are directed at maintaining internal corporate business relations, product flows or research projects. They take place in different ways (Millar and Salt 2008): In their most intensive form, management representatives may have numerous offices simultaneously at different sites and travel on a weekly basis between these sites that are located in different national cities or even near-by countries. Or, technical specialists may go back and forth to make sure that different production settings are in synchronicity with each other. This travel is often hierarchical in nature and involves center-periphery connections, directed from the headquarters to decentralized business locations, and vice versa. ${ }^{7}$

Goals of these meetings are related to the contextualization of knowledge as in the case of global R\&D communication (De Meyer 1991), as well as the maintenance of trust and the assurance of smooth and efficient relationships between different corporate units. The individuals going back and forth enable a high consistency in production, reliability in working on joint contracts, a clear-cut division of labor between corporate sites, and/or ongoing coordination in day-to-day decisions. To date, relatively little is known about the specific practices of knowledge generation in such configurations, other than that they seem to have gained in importance since the 1990s - despite increasing efforts to cut costs and despite the use of video-conferencing (Lu and Peeta 2009). It appears that such practices

\footnotetext{
${ }^{7}$ Empirical studies dealing with some forms of intra-firm business coordination include, for example, De Meyer (1991), McDonough et al. (1999) and Adenfelt (2010).
} 
generate a high level of control and ensure coherence across spatially decentralized production settings.

(ii) Cognitive focus and learning. The cognitive focus in these settings draws upon professional and personal continuity within a corporate setting and is driven by organizational proximity (Bathelt and Turi 2011). Through hyper-mobility, such configurations may generate settings of quasi-co-presence, based on very regular temporary meetings (e.g., Lassen 2006). One could almost say that distant production sites become neighbors through such practices. Rather than constantly communicating between diverse knowledge bases across different locations, it is the embodied knowledge base of one or few key managers that is being shared in these settings through frequent commutes. This allows for maximum synchronicity and fine-grained adjustments. Such practices of regular business coordination enable the transfer of both codified and highly complex tacit knowledge. Learning processes that are particularly important in such settings are based on participating simultaneously in different production environments.

(iii) Trust and risks. While the general production context may be highly complex and sensitive to coordination failure, such settings provide a relatively secure basis for interaction, aside from permanent co-presence and close spatial proximity, associated with medium to low risks. Through practices of temporary co-presence at different locations, trust is established and transferred between these locations. Regular interaction generates professional trust, but also stimulates personal trust (e.g., Glückler 2004). Mechanisms to prevent or sanction deviating behavior are basically the same as in the case of unified governance at a single location, ranging from replacing to firing key individuals.

\subsection{Producer-User Meetings}

(i) Framing. These meetings are part of ongoing producer-user relations, in which technical specialists get together with clients at the producer or user firms' sites, or in which 
service staff members regularly visit customers to adjust or renew existing relationships (Lundvall 1992; Gertler 2004). Such visits typically take place once or twice a year, or when some unexpected changes occur in the production or market context. Alternatively, such meetings may be driven by joint projects and involve collaboration with respect to the specific project goals (Ibert 2004). In these cases, meetings may occur more frequently (e.g., on a monthly basis), supported by electronic and digital communication.

The agenda behind such meetings involves maintaining a well-functioning inter-firm production setting, preparing new cooperation projects between firms and/or enquiring about the efficiency of existing producer-user arrangements. Goals are, on the one hand, to strengthen existing business relationships, and, on the other hand, to learn from customers and clients about ways of how to improve products and gain insights for future innovation. As such, these meetings are driven by processes of learning by interaction (von Hippel 1987; Lundvall 1992). ${ }^{8}$

(ii) Cognitive focus and learning. The cognitive focus of such meetings results from involving specialists who are part of specific communities of practice (Wenger 1998), although their basis can also be broader. The individuals engaged have complementary knowledge bases that generate interdependence between the respective firms over time within a common value-chain context. When interaction is focused on specific artifacts, such as complex machinery, knowledge exchanges involve specialized implicit knowledge, while discussions about potential future projects benefit from a balanced mixture of codified and tacit knowledge. Interaction that takes place in regular intervals is based on cognitivetechnological and quasi-organizational proximity (e.g., Rallet and Torre 2009).

\footnotetext{
${ }^{8}$ Empirical studies can be found in Britton (2003) and Gertler (2004), or, more broadly, Grabher et al.
} (2008). 
(iii) Trust and risks. The overall risk of interaction in such settings increases with growing transaction costs, especially related to higher frequency and factor specificity of transactions (Williamson 1985) - although pre-existing long-term relations with specific partners and joint histories of problem-solving may serve to keep uncertainties at bay. In any case, if deviant behavior becomes a problem, firms may enforce contractual penalties and eventually choose to exit existing relationships. Although this apparently does happen, interfirm relationships in many industry contexts are characterized by continuity and open-ended

relations (Bathelt and Glückler 2011). In producer-user relationships that have existed over a longer time period, professional and personal trust may become intermixed (e.g., Ettlinger 2003; Murphy 2006).

\subsection{Inter-firm Business Negotiations}

(i) Framing. In such settings, meetings may take place when a small number of firms prepare an intended joint strategic move in the near future. Related meetings involve only a few people, especially decision-makers and upper management representatives - sometimes also third parties like lawyers, consultants or subcontractors. They take place in a convenient, relaxed atmosphere (Ghauri 2003), preferably on 'neutral ground' (Mayfield et al. 1998), to allow participants to fully focus on developing their joint agenda further. The representatives of the firms might not know one another well and have possibly only met briefly at trade fairs or conventions in the past or been introduced to each other by e-mail through a lawyer or business association. In any case, these meetings bring together individuals from highly specialized communities that engage both in important pre-negotiations, during which they analyze each other's positions and exchange corresponding knowledge (Ghauri 2003), and in the negotiations themselves (so-called due diligence process), while, at the same time, getting to know one another better. Due to the complex task at hand, they meet regularly over a certain time period until their negotiations come to an end, or until they are broken up. 
Because of the substantial potential consequences of the outcome on either of the firms (e.g., in terms of employment or stock market effects), these meetings tend to be highly secretive and only few people might be informed about them. In terms of empirical evidence, little has been published about the knowledge generation practices during such meetings (e.g., Reynolds et al. 2003) - aside from studies about negotiation tactics and styles (e.g., Zhao 2000; Elahee and Brooks 2004) and about the goal of preventing knowledge to leak out, to avoid what Owen-Smith and Powell (2004) have described as a sprinkler effect.

The goal of these meetings is to prepare and sign a contract regarding an intended merger, acquisition or partnership between a limited number of firms, or to prepare some other strategic decision (e.g., a radical technological shift). This might, on the one hand, be a normal process during which goals are agreed upon and details of the contractual arrangements - including potential sanctions in the case of deviant behavior - are discussed. On the other hand, such meetings might involve elements of collusion and may be directed toward illegal market practices, such as hidden price fixing (Genesove and Mullin 2001). The meetings may end with a signed contract or without any agreement. In the latter case, there is a possibility that firms may depart from such meetings with bad feelings or adverse relationships, which may negatively impact future business performance.

(ii) Cognitive focus and learning. Such meetings are based on perceived identical goals, a shared knowledge base and joint understanding of the future industry or technology field. The agenda of such meetings may be to reconfirm cognitive proximity and transform this into organizational proximity (Nooteboom 2000), as well as to establish a knowledge base that contains tacit and codified elements in a codified form (e.g., technical hand/codebook).

(iii) Trust and risks. Since the results of such negotiations have potentially severe consequences and since the involved parties do not necessarily know one another well, the 
meetings are characterized by a high degree of uncertainty. Regular communication in a series of meetings may, thus, serve to create a professional trust basis (e.g., Bachmann 2001). Decision-makers use such meetings also to better understand each other's intentions and capabilities. All of this requires that the parties negotiate potential sanctions in detail, as described in transaction-cost theory (Williamson 1985). From the very beginning, exit is a realistic option in each party's set of possible actions. It is the combination of a relaxed atmosphere in a series of one-to-two-day project-related meetings, while also sharing personal information and getting to know each other better, through which both sides build up professional trust and reduce uncertainty. In other words, they use these meetings to check out the congruence of intentions and the existence of a 'shared chemistry' between the firms and individuals.

\section{Transnational Network Relations}

In comparison with international community gatherings and international business travel, transnational network relations represent a fundamentally different setting of knowledge transfer over distance. In the internationalization process, such settings are the expression of attempts to provide stronger corporate control over and closer ties to subsidiaries and branches in different countries often across different cultural and institutional settings (Dicken 2007). Corresponding network relations are organized in a way to provide access to decentralized local knowledge and markets in one or several host countries (Malecki 2010). Different constellations that can be found have in common that they are the result of firms seeking permanent proximity for some operations at the expense of long-distance relationships with the corporate core (Table 3). Often this involves that certain activities or functions are being relocated. Relationships with foreign operations are based on co-location (e.g. Ivarsson and Alvstam 2005), while former ties are transformed into long-distance relationships. 
Strategic moves to establish such networks involve foreign direct investments and are the expression of open-ended quasi-permanent commitments. Individuals linking these spatially separated sites involve transnational entrepreneurs, expatriates and/or family members. As boundary-spanners (Coe and Bunnell 2003), these agents create durable corporate linkages based on personal and professional relationships. They engage in ongoing communication and interaction through electronic and digital media that benefit from preexisting - sometimes primordial - relational ties (Amin and Cohendet 2004; Bouba-Olga and Grossetti 2008; Bathelt and Glückler 2011). Personal meetings take place more or less regularly and may last a few days - in the case of specific intra-firm projects, possibly even some weeks or months. Such transnational network settings are characterized by ongoing interaction punctuated by personal meetings with temporary face-to-face communication.

Insert Table 3 about here

\subsection{Transnational Corporate Networks}

(i) Framing. Transnational corporate networks are created when firms from one country establish subsidiaries or branches in another country via foreign-direct investments. No matter whether new affiliates are established as Greenfield or Brownfield investments, their activities eventually have to be integrated into the firm's overall activities (Glückler 2006). To guarantee control over this process and establish knowledge flows with other corporate affiliates and decision-making centers, firms designate experienced managers or technological experts quasi-permanently to the new locations, arranging a rotation of personnel after a period of one to four years (Millar and Salt 2008). These individuals connect the different cultural and institutional settings or networks between the home and host country and communicate with their corporate headquarters on a daily basis (Coe and 
Bunnell 2003). In addition, the distant localities are also linked through face-to-face meetings at the foreign branch or headquarter sites. ${ }^{9}$

Although boundary-spanning individuals may not always be at the top of the corporate hierarchy, their roles can be central to the success of transnational corporate networks (Depner and Bathelt 2005). The goal of such networks is to provide access to specific cultural and institutional characteristics of the host market that may stimulate rounds of innovations for the entire firm. The sort of market or technological knowledge targeted in this process may be difficult to access over distance (Dicken 2007). Boundary-spanners are, therefore, in place to secure both predictable and reliable knowledge and production flows across the corporate value chain (De Meyer 1991; Coe and Bunnell 2003). Their role is to mediate between different cultural and institutional contexts, to translate messages between them, and to create consistent structures.

(ii) Cognitive focus and learning. The common basis for communication between these sites is joint governance within a hierarchical corporate structure. The corresponding affiliates are characterized by organizational integration and generate permanent spatial proximity to new markets - while, at the same time, creating new distances on other ends of the corporation (Bathelt and Turi 2011). They connect knowledge pools in different countries and, depending on communicative capabilities and corporate-wide legitimacy, contribute to intra-firm cross-fertilization of these knowledge bases. Although initial investments may be experimental in character, commitments increase over time, while uncertainties persist. By

${ }^{9}$ Interesting empirical studies can be found in Ivarsson and Alvstam (2005), Depner and Bathelt (2005) or Glückler (2006). As opposed to intra-firm business travel discussed before that typically integrates national locations or sites in near-by countries, these connections do not only focus on corporate coordination but fundamentally employ bodily knowledge to connect different networks across different cultural, political and institutional settings, sometimes at a global level. 
investing in foreign markets, firms aim at getting access not only to explicit knowledge, but especially to implicit knowledge that is characteristic of such contexts (Ivarsson and Alvstam 2005).

(iii) Trust and risks. Uncertainties can be kept at bay through ongoing interaction, albeit that risks generally remain - for instance, related to intellectual property right infringements or conflicts between the domestic labor force and foreign leadership (Depner and Bathelt 2005). Such settings are based on high professional trust into the capabilities of the boundary-spanners in place. Due to regular communication, trust-based personal relationships may, of course, develop over time with contacts both in the home and host country. If, however, a boundary-spanner does not perform as well as expected or is not able to solve communication problems, the person will be displaced and relocated.

\subsection{New Transnational Firms}

(i) Framing. Like transnational corporate networks, new transnational firms generate transnational connections between the production and knowledge spheres of two or more countries. Corresponding linkages may be established by so-called 'Argonauts' (Saxenian 2006) who originate from developing countries or emerging markets and have left their country of origin to study or work in developed economies. Over time, they have developed competencies that enable them to identify market gaps and to establish new businesses in both their home and host country, while, at the same time, maintaining their contact networks and research activities on both sides. Other types of transnational firms are related to socalled transnational entrepreneurs who also typically originate in developing countries and establish new firms in industrialized host countries (Portes et al. 2002). The Argonauts and transnational entrepreneurs perform at least two decisive tasks at both ends of the networks they establish. First, they become executives and determine the direction of production and research across the different sites. Second, they operate as boundary-spanners and actively 
bridge the different cultural and institutional systems between the countries (Saxenian 2006). By exploiting intercultural knowledge, these firms gain competitive advantages compared to those who are located at just one location (Drori et al. 2009). As a consequence, the executieves frequently have to go back and forth between the production sites in both countries. Although this is often organized along a planned schedule, the need for spontaneous meetings makes such schedules obsolete at times. Aside from temporary face-toface coordination and decision-making, ongoing electronic and digital interaction guarantees synchronicity of actions. ${ }^{10}$

The goal of these transnational firms is to establish open-ended production networks between the home and host country locations in order to achieve specific cross-country competitive advantages (Hsu and Saxenian 2000; Drori et al. 2009). Since the governance structure of these firms is hierarchical, it is less difficult to achieve and exercise control over all contexts. Overall, the firms benefit from cognitive, cultural and spatial proximity, through which they stimulate growth at each end.

(ii) Cognitive focus and learning. The common basis for interaction is related to unified governance and competent experience-based knowledge of the production conditions in the different country contexts. Since investments and connections are meant to generate synergies, they focus on mobilizing complementary capabilities in the home and host countries. The decisive knowledge component in organizing these networks is implicit, but this is, of course, coupled with important codified knowledge. The key knowledge bases are embodied in the person of the entrepreneur and, possibly, few close executive members/assitants who also share a bi-cultural experience (e.g., Williams and Baláž 2008).

\footnotetext{
${ }^{10}$ Insightful studies of such transnational firm networks include Hsu and Saxenian (2000) and Portes et
} al. (2002). 
(iii) Trust and risks. Typically, these networks rely on personal relationships and involve both high personal and professional trust. Since few individuals around the entrepreneurs control strategic and day-to-day decision-making processes on all ends, the risks in interaction are kept at bay. When the professional character of these networks becomes dominant, however, uncertainties may increase and risks become greater. If such relationship networks do not work well or generate frictions, exit from a partnership and exclusion of the respective partner can be the consequence.

\subsection{Transnational Family Businesses}

(i) Framing. Transnational family businesses create wider production and business networks based on family relations, by the way of sending family members off to establish and control affiliates in other countries (Yeung 1997). Such organization results in rigid and closed forms of governing knowledge generation over distance, as discussed in empirical studies of Chinese family business networks (Tsang 2001) or transnational businesses of Indian families in the global diamond production and trade (Henn 2012; 2013). Because of close family ties, these businesses are under quasi-unified governance and, although they may be globally dispersed, there might not be a need for frequent or extended face-to-face meetings. When problems arise, they can likely be solved through electronic or digital forms of communication. Occasional meetings might be aligned with family celebrations or gettogethers and, thus, simultaneously serve multiple professional and social purposes. Face-toface meetings take place at the different family homes or sites of family events, and may not even include the firms' production/sales locations.

The goals of transnational family businesses are derived from a combination of professional and family-related agendas (Tsang 2001): On the one hand, production, trade and corresponding knowledge circulation are organized on a daily basis, following long-term goals that are often imposed by the family hierarchy. On the other hand, unique aspects 
family knowledge pool are applied to wider transnational production networks and to gain competitive advantages. Finally, another important incentive is to contribute to the overall family goals (Henn 2012).

(ii) Cognitive focus and learning. The cognitive focus for interaction in these networks and for the stability of knowledge circulation is based on strong relational ties between the members of the wider family who share an actual or imagined common background in terms of origin, history and corresponding myths, religion and ethnicity (Light 2010). Family members create an ideal institutional basis for economic interaction in situations, in which uncertainties of global interaction are very high. One could say that the actual or perceived 'joint genetic pool' establishes fundamental collective and mutual trust in these settings and becomes a precondition for learning and for establishing and maintaining transnational business linkages (Tsang 2001).

(iii) Trust and risks. The risks of such settings for knowledge transfers are low/minimal due to existing strong family ties. Such ties make it relatively easy to transfer all sorts of implicit and explicit, simple and complex, and public and secretive knowledge between globally dispersed firm sites (Henn 2013). Compliance is reinforced by family- and business-related codes of conduct and, in the case of misconduct, by the threat of being discharged from family and, by extension, business. Such punishment may be perceived as being more severe than an economic sanction alone.

\section{Conclusions}

This paper argues that there is a strong reflexive relationship between globalization processes and knowledge transfers over distance. On the one hand, the globalizing knowledge economy depends on complex practices of transfers of knowledge over distance that integrate different combinations of virtual communication with various forms of temporary face-toface interaction. On the other hand, the transfer of knowledge that is relevant to the 
coordination of production, future production processes and innovation increasingly relies on globalized transport and communication networks.

As knowledge transfer patterns are fundamentally structured by the nature and circumstances of the face-to-face contacts involved, a typology of knowledge transfer configurations is developed based on three principal dimensions that structure interaction: (i) framing conditions, (ii) cognitive focus/learning and (iii) trust/risks involved. Using these dimensions and related indicators, the paper identifies and systematically characterizes three main configurations of knowledge transfers over distance: (1) international community gatherings, such as trade fairs, conventions and conferences, (2) international business travel, including intra-firm business coordination, producer-user meetings and inter-firm negotiations, as well as (3) transnational network relations found in transnational corporate networks, new transnational firms and transnational family businesses.

While these configurations of knowledge transfers are not new, the multiple types and their widespread use throughout the economy suggest that these practices are inherent features of contemporary capitalism. Although it is beyond the scope of this paper to provide an in-depth investigation of capitalist dynamics, our analysis suggests that the differentiation and intensification of knowledge transfer practices over distance may have been both a precondition for and a consequence of the acceleration of modernity and its associated globalization processes, as powerfully described by Giddens (1984). Indeed, one could argue that the knowledge transfer practices discussed in this paper have been at the core of enabling neoliberalism (e.g. Peck 2010) to prosper and expand in the developed world, while simultaneously supporting selective catch-up processes or cementing under-development in less developed parts of the world.

Currently, we are facing manifold challenges to capitalism, related to the foreseeable effects of global climate change, peak oil and steeply increasing costs of mobility, possibly 
leading to a new scarcity economy in the future (Giddens 1984). These challenges not only point at massive future constraints in the transportation of goods and people that challenge the present state of globalization (Bridge 2010); these trends will also have important impacts on the global organization of economic processes, their reach and geographies, and the ways of how global linkages are maintained and reproduced. The knowledge transfer practices discussed in this paper can be regarded as parts of powerful experiments aiming to overcome these challenges towards a new period of capitalist accumulation (e.g., Hirsch 1990). Under these circumstances, related knowledge transfer practices over distance become imperative to secure and sustain global linkages and will, thus, gain in importance in the future.

When synthesizing the central findings of our analysis, broader patterns emerge that take the shape of global practices of learning and knowledge transfers. The above analysis suggests that regularities can be found when advancing from gatherings of communities through business travel towards network relations, as trust requirements between the agents involved increase and the types of knowledge at stake become more tacit in nature. While we reject a simplistic functionalist reasoning, our analysis reveals interesting tendencies in terms of how the nature and circumstances of these temporary face-to-face constellations vary and play out differently. We find that with growing uncertainty of interaction and increasing integration and commitment of activities, smaller groups of agents tend to be involved in knowledge generation, and these agents tend to communicate and meet more frequently. Along with this, the governance form of economic activities becomes more centralized, and more rigid mechanisms are put into place to reduce risks and sanction deviant behavior.

At closer investigation, we realize that the different learning settings are not separated, but are used in combination with other settings, thus complementing each other. For instance, transnational networks use regular business travel to learn from their national users while, at the same time, actively participating in international meetings to identify distant, yet 
complementary knowledge pockets. As a result, a variety of constellations of combined contexts of learning and knowledge transfers is established. The identified types of knowledge transfers over distance are, thus, not independent but build upon each other. For example, trade fair interaction may lead to the establishment of new transactions or new inter-firm negotiations about strategic shifts in the future, while producer-user-related knowledge transfer practices are being reconfirmed through periodical contacts during community gatherings.

At the same time, it needs to be emphasized that the geographies of knowledge transfers over distance are not self-sufficient. They depend, in particular, on two conditions that are intrinsically bound to these practices: (i) The first condition is related to the importance of bodily travel, face-to-face interaction and high personal mobility. This is based on the need to understand and overcome institutional, technological or simply language differences and assigns a key role to air travel in enabling timely mobility (e.g., Aguilera 2008; Wickham and Vecchi 2008; McDonough et al. 1999; Light 2010). (ii) The second condition rests on the intensive use of sophisticated communication media that enable frequent, high-quality communication via digital networks and communities (e.g., De Meyer 1991; Jeppesen and Molin 2003; Grabher et al. 2008).

Empirical evidence points at a strong interdependence between face-to-face meetings and different forms of electronic communication: Occasional face-to-face contacts are sometimes important preconditions for virtual communication since they introduce and reinforce trust between the parties involved (De Meyer 1991). Face-to-face meetings also generate substantial costs and do not guarantee that complex knowledge is immediately understood (McDonough et al. 1999; Millar and Salt 2008). Virtual communication should thus be viewed as a complementary form of interaction that enables distant learning and the transfer of knowledge. Since knowledge about the combination of temporary face-to-face 
contacts with ongoing virtual communication is limited at this point, an important avenue of future research will be to provide a better understanding of the integrative role of distant learning and knowledge transfer practices.

Finally, it becomes clear from a regional policy perspective that regions have different potentials for learning through these settings. In high-technology regions, we might find that global learning and knowledge transfer practices fundamentally rest on new transnational firms (e.g., Hsu and Saxenian 2000) or field-creating conferences (e.g., Möllering 2010), while regions in traditional industries might organize external learning primarily through transnational family firms (e.g., Henn 2012) and general market-related fairs. Regions with heavy industries, in turn, may rely on transnational corporate networks, as in the automobile industry (e.g., Depner and Bathelt 2005), and participate in global technology fairs. Related to this, another avenue of future research needs to systematically engage with questions as to why different region types develop different global learning patterns and how this is influenced by regional structures of social and economic relations.

\section{Acknowledgements}

Parts of this paper were presented at the 7th edition of the Proximity Days Conference at HEC Montreal in May 2012, and at the Annual Meeting of the Association of American Geographers in Los Angeles in April 2013 and the 35th DRUID Celebration Conference in Barcelona in June 2013. We would like to thank the participants of these conferences, particularly Bjørn Asheim, Rene Belderbos, Patrick Cohendet, Teis Hansen, Oliver Ibert, Andy Pratt, Larissa Rabbiosi, Allen Scott and Diane-Gabrielle Tremblay for providing insightful feedback. Particular thanks are due to Peng-Fei Li, Nigel Thrift and the anonymous Referees for thoughtful and stimulating comments that helped shape this paper, as well as for Ros Whitehead's superb editorial support. This research was funded through the Canada Research Chair in Innovation \& Governance at the University of Toronto.

\section{References}

Adenfelt, M. (2010) Exploring the performance of transnational projects: Shared knowledge, coordination and communication, International Journal of Project Management, 28, 529-538.

Aguilera, A. (2008) Business travel and mobile workers, Transportation Research Part A, 42, 1109-1116. 
Amin, A., Cohendet, P. (2004) Architectures of Knowledge: Firms, Capabilities, and Communities, Oxford, New York: Oxford University Press.

Bachmann, R. (2001) Trust, power and control in trans-organizational relations, Organization Studies, 22, 337-365.

Bateson, G. (1972) Steps to an Ecology of Mind. New York: Ballentine Books.

Bathelt, H., Glückler, J. (2011) The Relational Economy: Geographies of Knowing and Learning, Oxford: Oxford University Press.

Bathelt, H., Schuldt, N. (2010) International trade fairs and global buzz, Part I: Ecology of global buzz, European Planning Studies, 18, 1957-1974.

Bathelt, H., Turi, P. (2011) Local, global and virtual buzz: The importance of face-to-face contact and possibilities to go beyond, Geoforum, 42, 520-529.

Beaverstock, J.V., Derudder, B., Faulconbridge, J.R., Witlox, F. (2009) International business travel: Some explorations, Geografiska Annaler B, 91, 193-202.

Borghini, S., Golfetto, F., Rinallo, D. (2006) Ongoing search among industrial buyers, Journal of Business Research, 59, 1151-1159.

Boschma, R.A. (2005) Proximity and innovation: A critical assessment, Regional Studies, 39, 61-74.

Bouba-Olga, O., Grossetti, M. (2008) Socio-économie de proximité, Revue d'Economie Régionale et Urbaine, 3/2008, 311-328.

Bridge, G. (2010) Geographies of peak oil: The other carbon problem, Geoforum, 41:523-530.

Britton, J.N.H. (2003) Network structure of an industrial cluster: Electronics in Toronto, Environment and Planning A, 35, 983-1006.

Coe, N.M., Bunnell, T.G. (2003) 'Spatializing' knowledge communities: Towards a conceptualization of transnational innovation networks, Global Networks, 3, 437-456.

Coe, N.M., Dicken, P., Hess, M., Yeung, H.W-C. (2010) Making connections: Global production networks and world city networks, Global Networks, 10, 138-149.

Cohen, W.M. and Levinthal, D.A. (1990) Absorptive capacity: a new perspective on learning and innovation, Administrative Science Quarterly, 35, 128-152.

Coleman, J.S. (1990) Foundations of social theory, Cambridge, MA: Harvard University Press.

Cooke, P., Morgan, K. (1998) The Associational Economy, Oxford: Oxford University Press.

De Meyer, A. (1991) Tech talk: How managers are stimulating global R\&D communication, Sloan Management Review, 32, 49-58.

Depner, H., Bathelt, H. (2005) Exporting the German model: The establishment of a new automobile industry cluster in Shanghai, Economic Geography, 81, 53-81.

Dicken, P. (2007) Global Shift: Mapping the Changing Contours of the World Economy, 5th ed., New York: Guilford.

Dicken, P., Kelly, P.F., Olds, K., Yeung, H.W.-C. (2001) Chains and networks, territories and scales: Towards a relational framework for analyzing the global economy, Global Networks, 1, 89-112.

Drori, I., Honig, B., Wright, M., (2009) Transnational entrepreneurship: An emergent field of study, Entrepreneurship Theory and Practice, 33, 1001-1022.

Elahee, M., Brooks, C.M. (2004) Trust and negotiation tactics: Perceptions about business-tobusiness negotiations in Mexico, Journal of Business \& Industrial Marketing, 19, 397-404.

Ettlinger, N. (2003) Cultural economic geography and a relational and microspace approach to trusts, rationalities, networks, and change in collaborative workplaces, Journal of Economic Geography, 3, 145-172. 
Faulconbridge, J.R., Beaverstock, J.V., Derudder, B., Witlox, F. (2009) Corporate ecologies of business travel in professional service firms: Working towards a research agenda, European Urban and Regional Studies, 16, 295-308.

Fitjar, R.D., Rodriguez-Pose, A. (2011) Innovating in the periphery: Firms, values and innovation in Southwest Norway, European Planning Studies, 19, 555-574.

Garud, R. (2008) Conferences as venues for the configuration of emerging organizational fields: The case of cochlear implants, Journal of Management Studies, 45, 1061-1088.

Genesove, D., Mullin, W.P. (2001) Rules, communication, and collusion: Narrative evidence from the Sugar Institute case, American Economic Review, 91, 379-398.

Gereffi, G. (1994) The organization of buyer-driven global commodity chains: How US retailers shape overseas production networks, in Gereffi, G., Korzeniewicz, M. (eds), Commodity Chains and Global Capitalism, pp. 95-122. Westport, CT: Praeger.

Gereffi, G., Humphrey, J., Sturgeon, T. (2005) The governance of global value chains, Review of International Political Economy, 12, 78-104.

Gertler, M.S. (2003) Tacit knowledge and the economic geography of context, or The undefinable tacitness of being (there), Journal of Economic Geography, 3, 75-99.

Gertler, M.S. (2004) Manufacturing Culture: The Institutional Geography of Industrial Practice, Oxford, New York: Oxford University Press.

Ghauri, P.N. (2003) A framework for international business negotiations, in Ghauri, P.N., Usunier, J.-C. (eds) International Business Negotiations, pp. 3-22. Kidlington, Oxford: Elsevier.

Giddens, A. (1984) Consequences of Modernity, Stanford: Stanford University Press.

Glückler, J. (2004) Reputationsnetze. Zur Internationalisierung von Unternehmensberatern: Eine relationale Theorie (Reputation Networks. A Relational Theory About the Internationalization of Consulting Businesses), Bielefeld: Transcript.

Glückler, J. (2006) A relational assessment of international market entry in management consulting, Journal of Economic Geography, 6, 369-393.

Goffman, E. (1974) Frame Analysis. An Essay on the Organization of Experience, Cambridge, MA: Harvard University Press.

Grabher, G. (2003) Switching ties, recombining teams. Avoiding lock-in through project organization?, in Fuchs, G., Shapira, P. (eds), Rethinking regional innovation and change: Path dependency or regional breakthrough?, pp. 63-83. Boston, MA: Kluwer Academic Publishers.

Grabher, G. (2004) Learning in projects, remembering in networks? - Community, sociality and connectivity in project ecologies, European Urban and Regional Studies, 11, 103 123.

Grabher, G., Ibert, O., Flohr, S. (2008) The neglected king: The customer in the new knowledge ecology of innovation, Economic Geography, 84, 253-280.

Gulati, R. (1995) Does familiarity breed trust? The implications of repeated ties for contractual choice in alliances, Academy of Management Journal, 38, 85-112.

Henn, S. (2012) Transnational entrepreneurs, global pipelines and shifting production patterns: The example of the Palanpuris in the diamond sector, Geoforum, 43, 497506.

Henn, S. (2013) Transnational entrepreneurs and the emergence of clusters in peripheral regions: The case of the diamond cutting cluster in Gujarat (India), European Planning Studies, 21. DOI: 10.1080/09654313.2012.753690.

Herreros, F., Criado, H. (2008) The state and the development of social trust, International Political Science Review, 29, 53-71.

Hiller, H.H. (1995) Conventions as mega-events: A new model for convention-host city relationships, Tourism Management, 16, 375-379. 
Hirsch, J. (1990) Kapitalismus ohne Alternative? (Capitalism Without Alternative?), Hamburg: VSA.

Hsu, J.-Y., Saxenian, A. (2000) The limits of Guanxi capitalism: Transnational collaboration between Taiwan and the U.S., Environment and Planning A, 32, 1991-2005.

Humphrey, J., Schmitz, H. (2002) How does insertion in global value chains affect upgrading in industrial clusters?, Regional Studies, 36, 1017-1027.

Ibert, O. (2004) Projects and firms as discordant complements: Organisational learning in the Munich software ecology, Research Policy, 33, 1529-1546.

Ivarsson, I., Alvstam, C.G. (2005) The effect of spatial proximity on technology transfer from TNCs to local suppliers in developing countries: The case of AB Volvo in Asia and Latin America, Economic Geography, 81, 83-111.

Jeppesen, L.B., Molin, J.M. (2003) Consumers as co-developers: Learning and innovation outside the firm, Technology Analysis \& Strategic Management, 15, 363-383.

Jones, A. (2007) More than 'managing across borders'? The complex role of face-to-face interaction in globalizing law firms, Journal of Economic Geography, 7, 223-246.

Knorr Cetina, K. (1999) Epistemic Cultures: How the Sciences Make Sense, Chicago: Chicago University Press.

Ladkin, A., Spiller, J. (2000) Meetings, Incentives, Conferences and Exhibition Industry, London: Travel and Tourism Intelligence.

Lampel, J., Meyer, A.D. (2008) Field-configuring events as structuring mechanisms: How conferences, ceremonies, and trade shows constitute new technologies, industries, and markets, Journal of Management Studies, 45, 1025-1035.

Lassen, C. (2006) Aeromobility and work, Environment and Planning A, 38, 301-312.

Lawson, F.R. (1980) Congresses, conventions, and conferences: Facility supply and demand, International Journal of Tourism Management, 1, 184-188.

Leamer, E.E., Storper, M. (2001) The economic geography of the Internet age, Journal of International Business Studies, 32, 641-665.

Li, P.-F. (2012) Horizontal vs. vertical learning: Divergence and diversification in the Hangji toothbrush cluster, China, Regional Studies, 47. DOI: 10.1080/00343404.2012.709610.

Light, I. (2010) Transnational entrepreneurs in an English-speaking world, Die Erde, 141, 87102.

Lu, J.-L., Peeta, S. (2009) Analysis of the factors that influence the relationship between business air travel and videoconferencing, Transportation Research Part A, 43, 709721.

Lundvall, B.-Å. (1992) Introduction, in Lundvall, B.-Å. (ed.), National Systems of Innovation: Towards a Theory of Innovation and Interactive Learning, pp. 1-19. London: Pinter.

Malecki, E.J. (2010) Global knowledge and creativity: New challenges for firms and regions, Regional Studies, 44, 1033-1052.

Malmberg, A., Maskell, P. (2002) The elusive concept of localization economies: Towards a knowledge-based theory of spatial clustering, Environment and Planning A, 34, 429449.

Malmberg, A., Maskell, P. (2006) Localized learning revisited, Growth and Change, 37, 1-18.

Maskell, P., Bathelt, H., Malmberg, A. (2006) Building global knowledge pipelines: The role of temporary clusters, European Planning Studies, 14, 997-1013.

Mayfield, J., Maxfield, M., Martin, D., Herbig, P. (1998) How location impacts international business negotiations, Review of Business, 19, 21-24.

Maznevski, M.L., Chudoba, K.M. (2000) Bridging space over time: Global virtual team dynamics and effectiveness, Organization Science, 11, 473-492. 
McDonough, E.F., Kahn, K.B., Griffin, A. (1999) Managing communication in global product development teams, IEEE Transactions on Engineering Management, 46, 375-386.

McIntyre, E., Millar, S., Thomas, F. (2007) Convening a conference. Facilitating networking among delegates, Australian Family Physician, 36, 659-660.

McNeill, D. (2009) The airport hotel as business space, Geografiska Annaler B, 91, 219-228.

Millar, J., Salt, J. (2008) Portfolios of mobility: The movement of expertise in transnational corporations in two sectors - aerospace and extractive industries, Global Networks, 8, $35-50$.

Möllering, G. (2010) Collective market-making at an engineering conference, MPIfG Discussion Paper, 10/2, Cologne: Max-Planck-Institut für Gesellschaftsforschung.

Murphy, J.T. (2006) Building trust in economic space, Progress in Human Geography, 30, 427-450.

Nooteboom, B. (2000) Learning and Innovation in Organizations and Economies, Oxford: Oxford University Press.

Olson, C., Olson, J. (2003) Mitigating the effects of distance on collaborative intellectual work, Economics of Innovation and New Technology, 12, 27-42.

Owen-Smith, J., Powell, W.W. (2004) Knowledge networks as channels and conduits: The effects of spillovers in the Boston biotechnology community, Organization Science, $15,2-21$.

Peck, J. (2010) Constructions of Neoliberal Reason, Oxford: Oxford University Press.

Porter, M.E. (1990) The Competitive Advantage of Nations, New York: Free Press.

Portes, A., Sensenbrenner, J. (1993) Embeddedness and immigration: Notes on the social determinants of economic action, The American Journal of Sociology, 98, 1320-1350.

Portes, A., Guarnizo, L.E., Haller, W. (2002) Transnational entrepreneurs: An alternative form of immigrant economic adaptation, American Sociological Review, 67, 278-298.

Power, D., Jansson, J. (2008) Cyclical clusters in global circuits: Overlapping spaces and furniture industry trade fairs, Economic Geography, 84, 423-448.

Rallet, A. Torre, A. (1999) Is geographical proximity necessary in the innovation networks in the era of global economy?, GeoJournal, 49, 373-380.

Rallet, A., Torre, A. (2009) Temporary geographical proximity for business and work coordination: When, how and where?, SPACES, (2009-02), Heidelberg, Toronto: www.spaces-online.com.

Ramírez-Pasillas, M. (2008) Resituating proximity and knowledge cross-fertilization in clusters by means of international trade fairs, European Planning Studies, 16, 643-663.

Reynolds, N., Simintiras, A., Vlachou, E. (2003) International business negotiations: Present knowledge and direction for future research, International Marketing Review, 20, 236-261.

Rinallo, D., Golfetto, F. (2006) Representing markets: The shaping of fashion trends by French and Italian fabric companies, Industrial Marketing Management, 35, 856-869.

Rosson, P.J., Seringhaus, F.H.R. (1995) Visitor and exhibitor interaction at industrial trade fairs, Journal of Business Research, 32, 81-90.

Saxenian, A. (2006) The New Argonauts: Regional Advantage in a Global Economy, Cambridge: Harvard University Press.

Schuldt, N. and Bathelt, H. (2011) International trade fairs and global buzz, Part II: Practices of global buzz, European Planning Studies, 19, 1-22.

Short, J., Williams, E., Christie, B. (1976) The Social Psychology of Telecommunications, New York: Wiley.

Skov, L. (2006) The role of trade fairs in the global fashion business, Current Sociology, 54, 764-783. 
Thrift, N. (2000) Performing cultures in the new economy, Annals of the Association of American Geographers, 90, 674-692.

Tsang, E.W.-K. (2001) Internationalizing the family firm: A case study of a Chinese family business, Journal of Small Business Management, 39, 88-93.

von Hippel, E.A. (1987) Has a customer already developed your next product?, in Roberts, E.B. (ed.), Generating Technological Innovation, pp. 105-116. New York, Oxford: Oxford University Press.

Walther, J.B., Loh, T., Granka, L. (2005) Let me count the ways: The interchange of verbal and nonverbal cues in computer-mediated and face-to-face affinity, Journal of Language and Social Psychology, 24, 36-65.

Wenger, E. (1998) Communities of Practice: Learning, Meaning, and Identity, Cambridge: Cambridge University Press.

Wickham, J., Vecchi, A. (2008) Local firms and global reach: Business air travel and the Irish software cluster, European Planning Studies, 16, 693-710.

Williams, C.C., Baláž, V. (2008) International Migration and Knowledge. London: Routledge.

Williamson, O.E. (1985) The Economic Institutions of Capitalism: Firms, Markets, Relational Contracting, New York: Free Press.

Yeung, H.W.-C. (1997) Business networks and transnational corporations: A study of Hong Kong firms in the ASEAN region, Economic Geography, 73, 1-25.

Zelinsky, W. (1994) Conventionland USA: The geography of a latterday phenomenon, Annals of the Association of American Geographers, 84, 68-86.

Zhao, J.J. (2000) The Chinese Approach to International Business Negotiation, Journal of Business Communication, 37, 209-237. 
Table 1: Circumstances of International Community Gatherings

\begin{tabular}{|c|c|c|}
\hline Dimensions/indicators & Trade fairs & Conferences/conventions \\
\hline \multicolumn{3}{|l|}{ A. Framing } \\
\hline Actors involved & $\begin{array}{l}\text { Many (e.g., executives, } \\
\text { managers, technical specialists, } \\
\text { sales managers of an entire } \\
\text { industry) }\end{array}$ & $\begin{array}{l}\text { Numerous (e.g., specialized } \\
\text { managers, accepted experts, } \\
\text { members of associations, } \\
\text { politicians) }\end{array}$ \\
\hline Duration/periodicity & $\begin{array}{l}\text { Several days every year/every } \\
\text { few years }\end{array}$ & $\begin{array}{l}\text { Several days every year/every few } \\
\text { years }\end{array}$ \\
\hline Places of meetings & $\begin{array}{l}\text { Convention/exhibition/trade fair } \\
\text { centers }\end{array}$ & $\begin{array}{l}\text { Convention/exhibition/conference } \\
\text { centers/hotels }\end{array}$ \\
\hline \multirow[t]{2}{*}{$\begin{array}{l}\text { Expectations/goals of } \\
\text { participation }\end{array}$} & $\begin{array}{l}\text { Diffuse goals: presentation of } \\
\text { products; search for partners; } \\
\text { overview of markets; } \\
\text { comparison with competitors; } \\
\text { maintenance of networks }\end{array}$ & $\begin{array}{l}\text { Conferences: exchange/ } \\
\text { discussion of state-of-the-art } \\
\text { developments/experiences; search } \\
\text { for solutions; collective sense- } \\
\text { making on a specific theme }\end{array}$ \\
\hline & & $\begin{array}{l}\text { Conventions: showcasing recent } \\
\text { developments; achieving } \\
\text { consensus regarding future } \\
\text { developments }\end{array}$ \\
\hline \multicolumn{3}{|c|}{ B. Cognitive focus and learning } \\
\hline Common basis & $\begin{array}{l}\text { Broad overlapping industry-/ } \\
\text { technology-related communities }\end{array}$ & $\begin{array}{l}\text { Specialized, related knowledge } \\
\text { bases; common interests }\end{array}$ \\
\hline $\begin{array}{l}\text { Principal proximity } \\
\text { dimensions }\end{array}$ & Cognitive & Cognitive/social \\
\hline Knowledge circulated & $\begin{array}{l}\text { Largely codified, but also } \\
\text { systemic/architectural or design } \\
\text { knowledge with tacit elements }\end{array}$ & Primarily codified knowledge \\
\hline $\begin{array}{l}\text { Principal learning } \\
\text { mechanism }\end{array}$ & By interaction/observation & $\begin{array}{l}\text { Through transferring experience } \\
\text { (horizontal learning) }\end{array}$ \\
\hline \multicolumn{3}{|l|}{ C. Trust and risks } \\
\hline Stability in interaction & Initially short-term & Initially short-term \\
\hline Risks of interaction & Low & Low \\
\hline Role of trust & Not very important: swift trust & $\begin{array}{l}\text { Not very important: institutional/ } \\
\text { professional trust }\end{array}$ \\
\hline Potential sanctions & $\begin{array}{l}\text { Control by/rules of organizers: } \\
\text { may lead to exclusion }\end{array}$ & End/avoid communication \\
\hline
\end{tabular}


Table 2: Circumstances of International Business Travel

\begin{tabular}{|c|c|c|c|}
\hline Dimensions/indicators & $\begin{array}{l}\text { Intra-firm business } \\
\text { coordination }\end{array}$ & Producer-user meetings & $\begin{array}{l}\text { Inter-firm business } \\
\text { negotiations }\end{array}$ \\
\hline \multicolumn{4}{|l|}{ A. Framing } \\
\hline Actors involved & $\begin{array}{l}\text { Several (e.g., managers, } \\
\text { technical specialists) }\end{array}$ & $\begin{array}{l}\text { Several (e.g., managers, } \\
\text { technical specialists) }\end{array}$ & $\begin{array}{l}\text { Few (e.g., executives, } \\
\text { leading managers, third } \\
\text { parties) }\end{array}$ \\
\hline Duration/periodicity & $\begin{array}{l}\text { One day to few days } \\
\text { several times per year }\end{array}$ & $\begin{array}{l}\text { Several hours to few } \\
\text { days once to few times } \\
\text { per year }\end{array}$ & $\begin{array}{l}\text { One day to few days } \\
\text { several times per year }\end{array}$ \\
\hline Places of meetings & Corporate branches & $\begin{array}{l}\text { User or producer firms' } \\
\text { sites }\end{array}$ & $\begin{array}{l}\text { Luxurious hotels/ } \\
\text { venues on neutral } \\
\text { ground }\end{array}$ \\
\hline $\begin{array}{l}\text { Expectations/goals of } \\
\text { participation }\end{array}$ & $\begin{array}{l}\text { Assuring smooth and } \\
\text { efficient collaboration/ } \\
\text { division of labor/control }\end{array}$ & $\begin{array}{l}\text { Strengthening/adjust- } \\
\text { ing existing relations/ } \\
\text { discussion of new } \\
\text { collaborations }\end{array}$ & $\begin{array}{l}\text { Strategic agreement } \\
\text { over mergers/ } \\
\text { acquisitions/ } \\
\text { partnerships; potential } \\
\text { collusion }\end{array}$ \\
\hline \multicolumn{4}{|c|}{ B. Cognitive focus and learning } \\
\hline Common basis & $\begin{array}{l}\text { Unified governance; } \\
\text { identical hyper-mobile } \\
\text { knowledge base }\end{array}$ & $\begin{array}{l}\text { Complementary value- } \\
\text { chain-related } \\
\text { knowledge base }\end{array}$ & $\begin{array}{l}\text { Perceived identical } \\
\text { goals/visions of the } \\
\text { industry/firms }\end{array}$ \\
\hline $\begin{array}{l}\text { Principal proximity } \\
\text { dimensions }\end{array}$ & Organizational & $\begin{array}{l}\text { Cognitive/quasi- } \\
\text { organizational }\end{array}$ & $\begin{array}{l}\text { Cognitive/planned } \\
\text { organizational }\end{array}$ \\
\hline Knowledge circulated & $\begin{array}{l}\text { Codified/complex tacit } \\
\text { knowledge }\end{array}$ & $\begin{array}{l}\text { Tacit in problem- } \\
\text { solving, but also } \\
\text { codified }\end{array}$ & $\begin{array}{l}\text { Implementation of tacit/ } \\
\text { codified knowledge }\end{array}$ \\
\hline $\begin{array}{l}\text { Principal learning } \\
\text { mechanism }\end{array}$ & Through participation & By interaction & $\begin{array}{l}\text { By trust-building; } \\
\text { through due diligence }\end{array}$ \\
\hline \multicolumn{4}{|l|}{ C. Trust and risks } \\
\hline Stability in interaction & Open-ended/immanent & Several years or longer & $\begin{array}{l}\text { Project-related: } \\
\text { several/multiple months }\end{array}$ \\
\hline Risks of interaction & $\begin{array}{l}\text { Medium/low: similar to } \\
\text { one integrated location }\end{array}$ & $\begin{array}{l}\text { Increasing with growing } \\
\text { transaction costs }\end{array}$ & $\begin{array}{l}\text { High; potentially } \\
\text { asymmetric knowledge }\end{array}$ \\
\hline Role of trust & $\begin{array}{l}\text { Regularity reduces need } \\
\text { for trust, while creating } \\
\text { personal trust }\end{array}$ & $\begin{array}{l}\text { Professional trust; } \\
\text { personal relations over } \\
\text { time }\end{array}$ & $\begin{array}{l}\text { Professional trust } \\
\text { through regular } \\
\text { meetings }\end{array}$ \\
\hline Potential sanctions & $\begin{array}{l}\text { Replacement/firing of } \\
\text { key individuals }\end{array}$ & $\begin{array}{l}\text { Contractual penalties; } \\
\text { exit }\end{array}$ & $\begin{array}{l}\text { Negotiable penalties; } \\
\text { exit }\end{array}$ \\
\hline
\end{tabular}


Table 3: Circumstances of Transnational Network Relations

\begin{tabular}{|c|c|c|c|}
\hline Dimensions/indicators & $\begin{array}{l}\text { Transnational corporate } \\
\text { networks }\end{array}$ & New transnational firms & $\begin{array}{l}\text { Transnational family } \\
\text { firms }\end{array}$ \\
\hline \multicolumn{4}{|l|}{ A. Framing } \\
\hline Actors involved & Few (expatriates) & $\begin{array}{l}\text { Few (transnational } \\
\text { entrepreneurs/ } \\
\text { Argonauts) }\end{array}$ & $\begin{array}{l}\text { Few (professional } \\
\text { family members) }\end{array}$ \\
\hline Duration/periodicity & $\begin{array}{l}\text { Daily interaction with } \\
\text { regular yearly meetings }\end{array}$ & $\begin{array}{l}\text { Daily interaction with } \\
\text { regular/irregular meet- } \\
\text { ings }\end{array}$ & $\begin{array}{l}\text { Frequent interaction; } \\
\text { occasional meetings - } \\
\text { often within family } \\
\text { context }\end{array}$ \\
\hline Places of meetings & $\begin{array}{l}\text { Foreign branches or } \\
\text { headquarter site }\end{array}$ & $\begin{array}{l}\text { Transnational net- } \\
\text { work/firm sites }\end{array}$ & Private homes/firm sites \\
\hline $\begin{array}{l}\text { Expectations/goals of } \\
\text { participation }\end{array}$ & $\begin{array}{l}\text { Connecting different } \\
\text { cultural/institutional } \\
\text { knowledge pools; } \\
\text { coordination }\end{array}$ & $\begin{array}{l}\text { Establishment of } \\
\text { durable production } \\
\text { linkages; realization of } \\
\text { cross-country } \\
\text { competitive advantages }\end{array}$ & $\begin{array}{l}\text { Long-term family/ } \\
\text { professional goals; } \\
\text { close coordination of } \\
\text { global production }\end{array}$ \\
\hline \multicolumn{4}{|c|}{ B. Cognitive focus and learning } \\
\hline Common basis & $\begin{array}{l}\text { Joint governance } \\
\text { through boundary- } \\
\text { spanning }\end{array}$ & $\begin{array}{l}\text { Unified governance; } \\
\text { embodied experience; } \\
\text { strong interdependence }\end{array}$ & $\begin{array}{l}\text { Close family ties; } \\
\text { shared history/values; } \\
\text { joint family codes }\end{array}$ \\
\hline $\begin{array}{l}\text { Principal proximity } \\
\text { dimensions }\end{array}$ & $\begin{array}{l}\text { Organizational/ } \\
\text { relational }\end{array}$ & $\begin{array}{l}\text { Cognitive/cultural/ } \\
\text { relational }\end{array}$ & Relational/cultural \\
\hline Knowledge circulated & Tacit, but also codified & $\begin{array}{l}\text { Tacit with codified } \\
\text { components }\end{array}$ & Tacit/codified \\
\hline $\begin{array}{l}\text { Principal learning } \\
\text { mechanism }\end{array}$ & Through translation & $\begin{array}{l}\text { By exploiting inter- } \\
\text { cultural knowledge }\end{array}$ & $\begin{array}{l}\text { From a 'joint genetic } \\
\text { pool' }\end{array}$ \\
\hline \multicolumn{4}{|l|}{ C. Trust and risks } \\
\hline Stability in interaction & $\begin{array}{l}\text { Medium-term (several } \\
\text { years) }\end{array}$ & Open-ended & Quasi-permanent \\
\hline Risks of interaction & $\begin{array}{l}\text { Medium, but conflicts } \\
\text { may arise }\end{array}$ & $\begin{array}{l}\text { Higher in professional } \\
\text { than in personal net- } \\
\text { works }\end{array}$ & Low \\
\hline Role of trust & $\begin{array}{l}\text { High professional trust; } \\
\text { personal trust develops } \\
\text { over time }\end{array}$ & $\begin{array}{l}\text { Relatively high in } \\
\text { professional/very high } \\
\text { in personal networks }\end{array}$ & $\begin{array}{l}\text { Extremely high: } \\
\text { collective mutual trust } \\
\text { without prior } \\
\text { investments }\end{array}$ \\
\hline Potential sanctions & $\begin{array}{l}\text { Displacement/ } \\
\text { relocation }\end{array}$ & $\begin{array}{l}\text { Exit/exclusion/con- } \\
\text { tractual penalties }\end{array}$ & Discharge from family \\
\hline
\end{tabular}

